\title{
Assessment of the Environmental Values of Waste-to-Energy in the Gaza Strip
}

\author{
OMAR K.M. OUDA \\ Department of Civil Engineering, Prince Mohamed Bin Fahd University, \\ Al Khobar, Kingdom of Saudi Arabia. \\ http://dx.doi.org/10.12944/CWE.8.3.03
}

(Received: October 26, 2013; Accepted: November 17, 2013)

\begin{abstract}
The Gaza Strip faces a chronic solid waste (SW) management and electricity shortage problem as a result of fifty years of political instability in the area coupled with a high population growth rate, an unhealthy economic condition, and limited land and energy resources. The option to develop a waste to energy (WTE) facility to manage SW and to alleviate the electricity shortage has not been previously investigated for the Gaza Strip. This paper assesses the potential environmental and economic benefit of a WTE facility on the context of two scenarios: Mass Burn and Mass Burn with Recycling up to the year 2035. The analysis shows a potential to generate approximately 77.1 Megawatts (MW) of electricity based on a Mass Burn scenario and approximately 4.7 MW of electricity based on a Mass Burn with Recycling scenario. These values are approximately $10.3 \%$ and $0.63 \%$ respectively of the projected peak electricity demand of 751 MW in 2035. The research identifies the potentially significant environmental benefit of developing WTE facilities within the Gaza Strip. The Mass Burn with Recycling scenario shows a potential greenhouse gases emission reduction of approximately 92 thousand metric tons carbon equivalent (MTCE) per year, and landfill area savings of about $94 \%$ in comparison to complete landfilling in 2035. Further investigation is recommended to evaluate the socio-economic impacts and technical feasibility of the development of WTE facilities for the Gaza Strip.
\end{abstract}

Key words: Gaza Strip, Waste-to-Energy, Solid Waste, Greenhouse Gases, Landfill.

\section{INTRODUCTION}

The Gaza Strip is located in the Middle East bounded by the Mediterranean Sea to the West, Egypt to the South and Israel to the North and West, and has a total area of $365 \mathrm{~km}^{2}$. It is $45 \mathrm{~km}$ in length and 5 to $7 \mathrm{~km}$ in width in the north to a maximum of $12 \mathrm{~km}$ in width in the South as, as shown in Fig $1^{1}$. The Gaza Strip's population was about 1.65 million in 2010 with a population density of about 4,520 capita per square kilometer, which is the highest population density in the world 2,3 . Three decades (1967 to 1994) of Israeli military occupation and two decades of political instability have caused a complete deterioration of the solid waste (SW) and electricity system infrastructure in the Gaza Strip ${ }^{4}$ The electricity peak demand was approximately 360 MW in 2012 which was partially supplied through the following three resources: the Gaza Power Plant (GPP) providing about 100 MW, 120 MW purchased from Israel and $22 \mathrm{MW}$ purchased from Egypt ${ }^{6,7}$. The deficit between electricity demand and supply causes eight to twelve hours of scheduled power outages per day. These disruptions have caused great hardships to human life, including the proper functioning of education and health institutions, and the operation of water and sewage systems. Power outages also hinder the economy, especially businesses in the industrial and agricultural sectors ${ }^{7}$.

The SW management system in the Gaza Strip is simple and includes the collection of refuse and disposing of it in open landfill sites or open dumpsites. There are three open landfills and dumping sites in the Gaza Strip. These facilities 
are overloaded and have exceeded their storage capacities. SW generation was estimated to range from 0.4 to $0.6 \mathrm{~kg} /$ capita/day in rural areas and refugee camps, and 0.9 to $1.2 \mathrm{~kg} /$ capita/day in cities $^{4,8}$. This situation caused serious public health and environmental problems, specifically to groundwater aquifers, which are already in poor condition ${ }^{4}$. The shortage of available land resources to construct new landfills, and limited energy sources coupled with high population growth has resulted in extra stress to the SW management and to electricity systems in the Gaza Strip. The option to develop WTE facilities to manage the solid waste problem and to alleviate the electricity shortage has not been previously investigated in the Gaza Strip. This research aims to assess the potential environmental and economic benefit of developing waste to energy (WTE) facilities in the Gaza Strip on the context of two scenarios: Mass Burn and Mass Burn with Recycling up to the year 2035. The research reviews SW management and the electricity demand vs. supply in the Gaza Strip; estimates the potential contribution from waste-to-energy facilities to electricity peak demand in the Gaza Strip, and calculates the greenhouse gases emission reduction and landfill area saving for the two scenarios.

\section{Municipal Solid Waste Sector}

The current main issues with SW management are identification and selection of the most appropriate SW treatment technologies and disposal methods in selected areas ${ }^{22}$. In developing countries, the issues are additional complicated due to poor SW management and limited financial and technical resources. SW management in the Gaza Strip is in a state of disarray due to years of occupation and undesirable economic conditions. Municipalities handle SW in urban and rural areas while United Nations (UN) manages SW collection and disposal associated with the eight refugee camps in the Gaza Strip. Most of SW is collected by temporary workers using donkey carts and push carts ${ }^{4}$. The Gaza Strip's SW composition includes $60.8 \%$ organic materials, $16.1 \%$ plastics, $8.4 \%$ paper, $3.8 \%$ textile, $2.3 \%$ glass, $2.8 \%$ metals, $0.8 \%$ wood, and $5 \%$ other $^{10}$. The Gaza Strip's municipalities utilize open dumpsites within the city boundaries as transfer stations which pose a direct risk to soil and groundwater quality in the area. For example, Gaza City municipality uses around 150 donkey carts for waste collection. The collected waste is shipped to open transfer sites within the city boundary. From this point, approximately 20 vehicles transport the waste to the Jahr El Deek landfill located south of Gaza City ${ }^{10}$. Currently there are three landfills in Gaza Strip: Jahr El Deek, Deir El Balah, and Rafah. The three landfills are currently exceeding their maximum storage capacities ${ }^{10}$. The Jahr El Deek Landfill serves Gaza City and Northern Gaza communities. It is located southeast of Gaza City and contains about 3 million tons of waste so far, and does not have any environmental protection measures such as liner systems or leachate control. Deir El Balah's landfill is located east of Deir EI Balah City and serves the Central Gaza Strip communities. It has been constructed as a sanitary landfill with support from the German government and contains about 300 thousand tons of waste as of 2012. Rafah Landfill is located east of Rafah City and serves the Southern Gaza Strip communities. Its design does not incorporate any environmental protection measures and contains about 1.6 million tons of waste as of $2012^{10}$. The municipalities collect the waste collection fees from households and companies. The SW sector has been supported by foreign donors since 1994 . The total grants provided since 1994 was about 72 million Euros for the West Bank and Gaza Strip. Most of the grants were spent on infrastructure projects for waste collection, transport, disposal, and capacity development ${ }^{10}$. The private sector runs SW recycling systems for valuable materials such as plastic and metals. Most of valuable materials are recovered from the waste streams prior arrival to the landfills. Plastic materials are recycled at four plastic factories in the Gaza strip where plastic materials are used to produce plastic bags and pipes. Metals are segregated from the waste stream and exported to Israel ${ }^{10}$. The recycling system is not regulated and is solely implemented by the private sector without any governmental involvement and is driven by the recycled materials' high financial value. There are a few waste composting initiatives in the Gaza Strip including a pilot project in Rafah City, south of Gaza Strip, established by the Palestinian Friends Society, an Non Government Organization (NGO), and another small pilot project at Beit Lahia north of the Gaza 
Strip financed by CRIC, which is an Italian NGO and managed by United Nations Development Program ${ }^{10}$. The high population growth rate and the population density in the Gaza Strip has added significant pressure on Gaza's land resources which has limited land availability for new landfills or expansion of the existing landfills.

\section{Electricity Sector}

The Gaza Strip has been completely dependent on Israel for its electricity supply since 1967. Following the establishment of the Palestinian National Authority (PNA) in 1994; the first attempt towards electricity independency and selfsufficiency was taken through the establishment of the Palestinian Electricity Company (PEC) and the construction of the Gaza Power Plant (GPP) which was completed in $2002^{\circ}$. The GPP has a production capacity of $140 \mathrm{MW}$ and it operates on industrial diesel fuel. Industrial diesel is imported from Israel and the PEC is completely dependent on Israel for the transfer of the spare parts required for operation of the power plant that is supplied from Israeli or foreign companies ${ }^{7}$. The political instability of the area and Israeli control of diesel and the spare parts supply have limited the production efficiency and supply capacity of the GPP. Recently a marine offshore gas field has been discovered off the shores of Gaza, which has the potential to supply all the energy demand of the Gaza Strip ${ }^{5,6}$. The field has never been developed due to political instability in the area. PNA is planning to increase the diversity of its electricity resources through the utilization of renewable energy sources, such as solar, wind, biomass and Waste to Energy, to meet its future energy demands. Currently renewable resources provide about $18 \%$ of total energy consumption in Palestine, mainly solar energy ${ }^{9}$.

The review of the Gaza Strip's electricity system and the SW service shows that the existing landfills have exceeded their capacities and electricity shortage is a chronic problem. These issues are expected to get worse with time due to a high population growth rate in the Gaza Strip with an average of $3.25 \%$ in the last two decades, which will result in substantial increases in electricity demand and SW generation. Available options to generate electricity to reduce the gap between electricity demand and supply are very limited as a result of the current political situation and limited fuel sources. Sanitary landfilling is an expensive option due to the land resource limitations in the Gaza Strip resulting from a high population growth rate and density. Waste to energy systems can reduce the amount of SW deposited in landfill sites by up to $90 \%$ depending upon material composition and degree of recovery ${ }^{11}$, which in turn can reduce the area required for landfilling by about $90 \%$.

\section{Research Mothodology}

Two scenarios were developed to assess the potential contribution of WTE facilities to meeting the total electricity demand in the Gaza Strip up to the year 2035: Mass Burn and Mass Burn with Recycling. The Mass Burn scenario implies full utilization of SW for WTE production. Mass Burn with Recycling assumes removal of recyclable materials from the waste stream and utilizing the remaining SW for WTE production. The year 2012 was chosen as the starting year for forecasting. The MSW production rate was assumed to be $0.9 \mathrm{~kg} / \mathrm{capita} /$ day for the forecasted period. The SW contents were considered as per UNDP-PAPP 2012, mentioned in Section 1. The caloric energy content of the various types of waste is presented in Table $1^{12,13}$. These values were used to calculate the total energy content per kilogram of the Gaza Strip's SW for the two scenarios. There are a number of developed and emerging technologies that are able to produce energy from waste, however the most widely proven and used WTE technology is the process of producing energy in the form of heat and/or electricity from waste sources via combustion ${ }^{14,15,16}$. Research literature has identified a combustion efficiency of $25 \%$ to $30 \%$ for existing WTE facilities in different places across the globe ${ }^{18,19}$. A combustion efficiency of $25 \%$ will be assumed in calculating the WTE for the Gaza Strip.

Greenhouse gases emission reduction for the two scenarios was calculated following US EPA methodologies as reported in US EPA 2006. Greenhouse gases emission reduction compared to landfilling for recycling and combustion in Metric Ton Carbon Equivalent per ton of materials (MTCE/ ton) are presented in Table 2. These values were used to calculate the greenhouse gases emission reduction per ton of Gaza's SW for the two scenarios 
up to year 2035.

Sizing of the landfill area requires estimates of the rate at which wastes are discarded at and the density of these wastes within the landfill. The SW density in a landfall ranges from $500 \mathrm{~kg} /$ $\mathrm{m}^{3}$ to $700 \mathrm{~kg} / \mathrm{m}^{3}$, with a reasonable average estimate of about $600 \mathrm{~kg} / \mathrm{m}^{313}$. WTE reduces the amount of SW deposited at landfill sites by $90 \%$ on terms of volume reduction and $80 \%$ in terms of mass ${ }^{11,13,17}$. Incineration also minimizes leachate and methane formation and odor emissions ${ }^{11}$. The thickness of the landfill is typically in the order of $3 \mathrm{~m}$ depth ${ }^{13}$. Using these values, the area landfill area requirements were calculated for the two WTE scenarios.

\section{RESULTS AND DISCUSSIONS}

The Gaza Strip's population was about 1.65 million in 2010 and had an average historical growth rate ranging from $3.0 \%$ to $3.5 \%$ for the last two decades ${ }^{2,3}$, and a population density of about 4,520 capita per square kilometer. The population is expected to continue growing at this rate given the cultural norms of Palestinian reproductive behavior and the social and religious culture of the area. The forecasted population in the Gaza Strip based on growth rate of $3.25 \%$ up to the year 2035 is presented in Fig 2. In 2035, the population of the Gaza Strip is expected to reach 3.4 million which is about twice the 2010 population of about 1.65 million.

The 2012 electricity peak demand in Gaza Strip was as high as $360 \mathrm{MW}$ for a population of 1.65 million. The electricity peak demand was forecasted up to the year 2035 based on projected population growth and the per capita electricity demand. The electricity peak demand in Gaza strip is expected to reach $550 \mathrm{MW}$ and $750 \mathrm{MW}$ by the years 2020 and 2035; respectively, as shown in Fig 3. It should be noted that the population and electricity peak forecast results are in general agreement with the UN estimate as presented in the UN report titled: Gaza in 2020 A livable place ${ }^{6}$.

\section{SW Generation Forecast Results}

The forecasted increase of the Gaza Strip's population is substantial, and will come with huge increases in the quantity of generated SW.
The forecasted annual generation of SW up to year 2035 is presented in Fig 4. The 2010 SW quantity was approximately 505 thousand tons and is estimated to reach about 1.124 million tons in 2035. This is a substantial amount of SW and should be managed wisely. Taking into consideration that the existing landfills in the Gaza Strip have already exceeded their capacity and the limited land resources in the area, management of the MSW following the current practices will result in huge environment and financial consequences.

The MSW generated in the Gaza Strip contains many valuable materials such as paper, plastics, metals, glass and textile products that can be sold at attractive market prices. Recycling is already practiced in the Gaza Strip on a wide scale, where most plastics and metals are recycled as discussed in Section 1.1. The forecast to 2035 for the potential amount of recyclable materials is presented in Figure 5. The values on the figure below show a huge potential for recycling in the Gaza Strip. The current recycling practices are not regulated and are conducted by the private sector mainly. Recycled materials are typically removed from the waste stream at source. The high potential for recyclable materials warrants further investigation in order to assess the value of developing a materials recovery facility in the Gaza Strip. The decision to recycle these materials or to mass burn them will require further investigation to determine the financial and environmental merits and disadvantages of both approaches.

\section{WTE Energy Production Forecast Results}

The energy content of Gaza Strip MSW was calculated based on the caloric content of SW materials (Table 1), and the SW composition as presented in Section 2. Table 3 shows the energy contents of different materials in kW per kilogram $(\mathrm{kg})$ of MSW. Two sets of values of the energy content per $\mathrm{kg}$ of SW were calculated for the Mass Burn scenario and Mass Burn with Recycling scenario, and found to be $2.41 \mathrm{kWh} / \mathrm{Kg}$ and $0.43 \mathrm{kWh} / \mathrm{Kg}$ respectively. The large difference between the energy content of the two scenarios was a result of removing the materials that have high energy contents (plastic, paper, wood, and textiles) from the Mass Burn scenario and considering them for recycling purposes. 
The electricity production potential for the two scenarios is presented in Figure 6. The Mass Burn with recycling scenario results shows a potential to produce about 4.7 Megawatt (MW) of electricity from SW by the year 2035. This value forms about $0.63 \%$ of the estimated $751 \mathrm{MW}$ peak electricity demand in 2035. The Mass Burn scenario shows the potential to produce about $77.1 \mathrm{MW}$ of electricity from SW by the year 2035, which is about $10.3 \%$ of the $751 \mathrm{MW}$ peak demand in 2035 .

\section{Environmental Values}

Landfills are major source of greenhouse gases, which contribute about $3.4 \%$ to $3.9 \%$ of

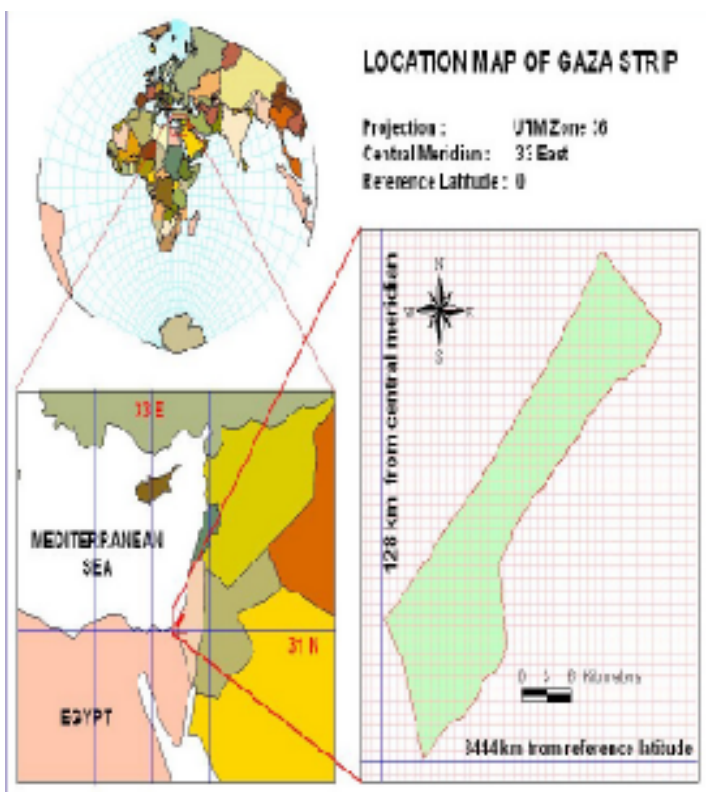

Fig 1:The Gaza Strip Location Map ${ }^{12}$ global greenhouse gases emissions ${ }^{21}$. During SW decomposition, large quantities of methane and carbon dioxide are produced, and released into the atmosphere. Methane is 21 times more detrimental as greenhouse gases than is carbon dioxide $^{19,21}$. The potential reduction in greenhouse gasses for processing of waste using the Mass Burn with Recycling and Mass Burn scenarios in comparison to landfilling were calculated. The calculations were completed under the consideration of the net greenhouse gases reduction potential for the various components of SW as presented in Table 2 and the Gaza's SW composition. Table 4 presents the greenhouse gases reduction per ton of Gaza's SW. Two values of the greenhouse gases reductions per ton of SW were calculated for the Mass Burn with Recycling scenario and Mass Burn scenario. The results show the potential to reduce greenhouse gases emissions based on Mass Burn with recycling scenario of about 0.34 MTCE per ton of SW material and about 0.08 MTCE per ton of SW materials based on Mass Burn scenario.

The greenhouse gases reduction potential in comparison to landfilling for the two scenarios is presented in Fig 7 . Fig 7 shows that applying a comprehensive recycling program as part of Mass Burn with Recycling scenario will ultimately result in a reduction of greenhouses gases emission of about 93 thousand MTCE in 2035. The Figure also shows that Mass Burn scenario will ultimately reduce greenhouse gasses by about 32 thousand MTCE in comparison to projected landfill emissions in 2035. The

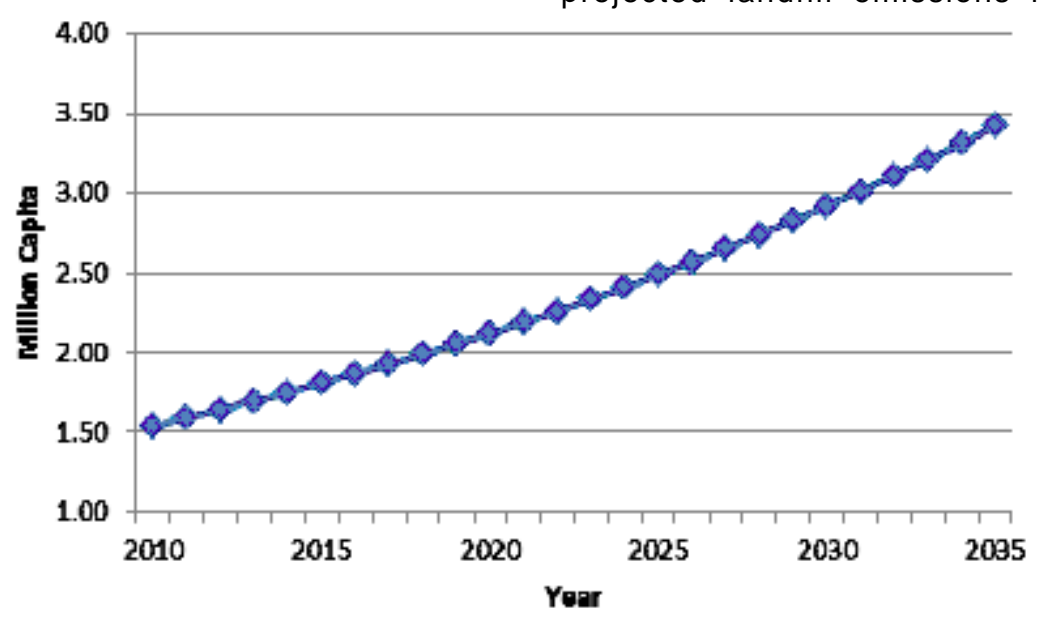

Fig 2: Gaza Strip Population Forecast Results 


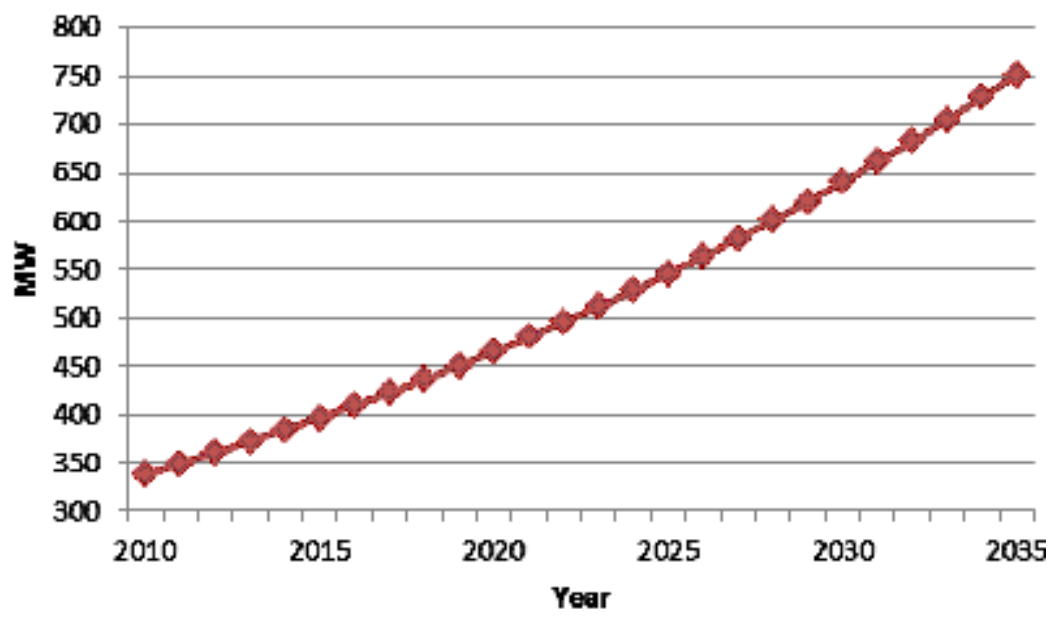

Fig 3: Gaza Strip Peak Electricity Demand Forecast Results.

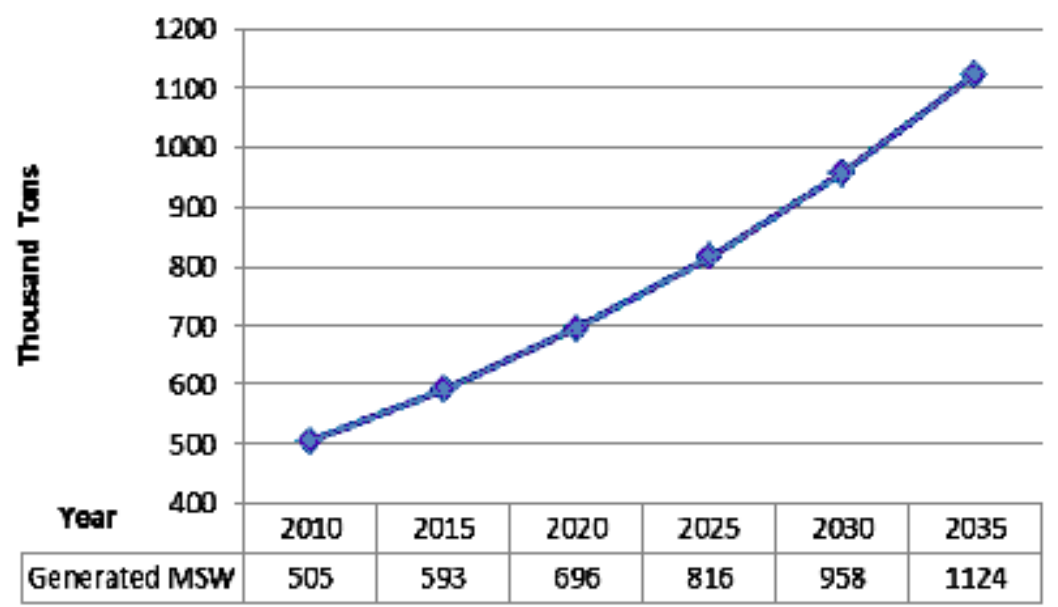

Fig 4:The Gaza Strip MSW Generation Forecast Results

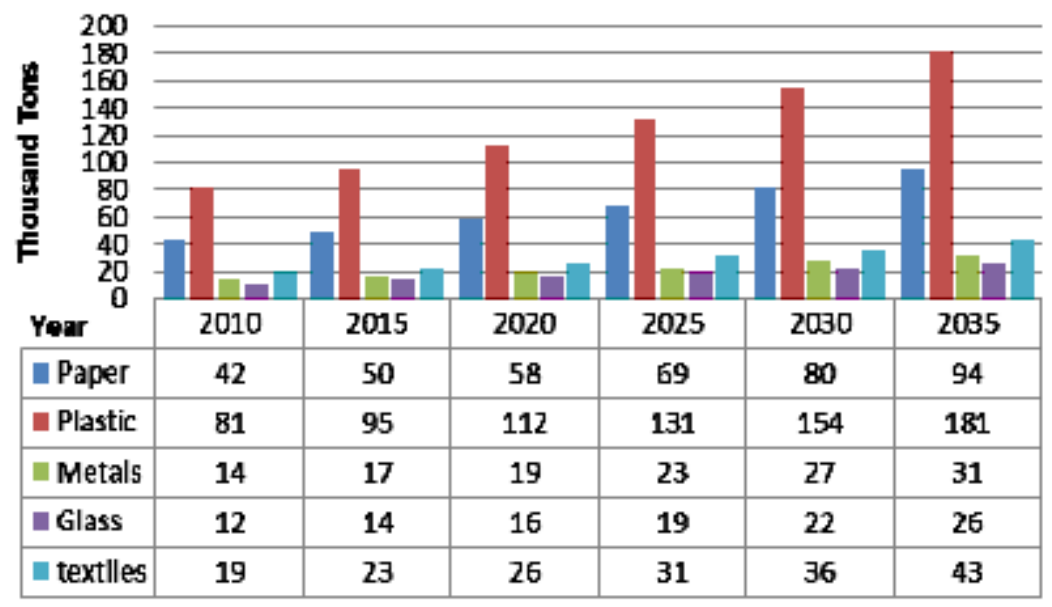

Fig 5: MSW Recycled Materials Forecast Results. 


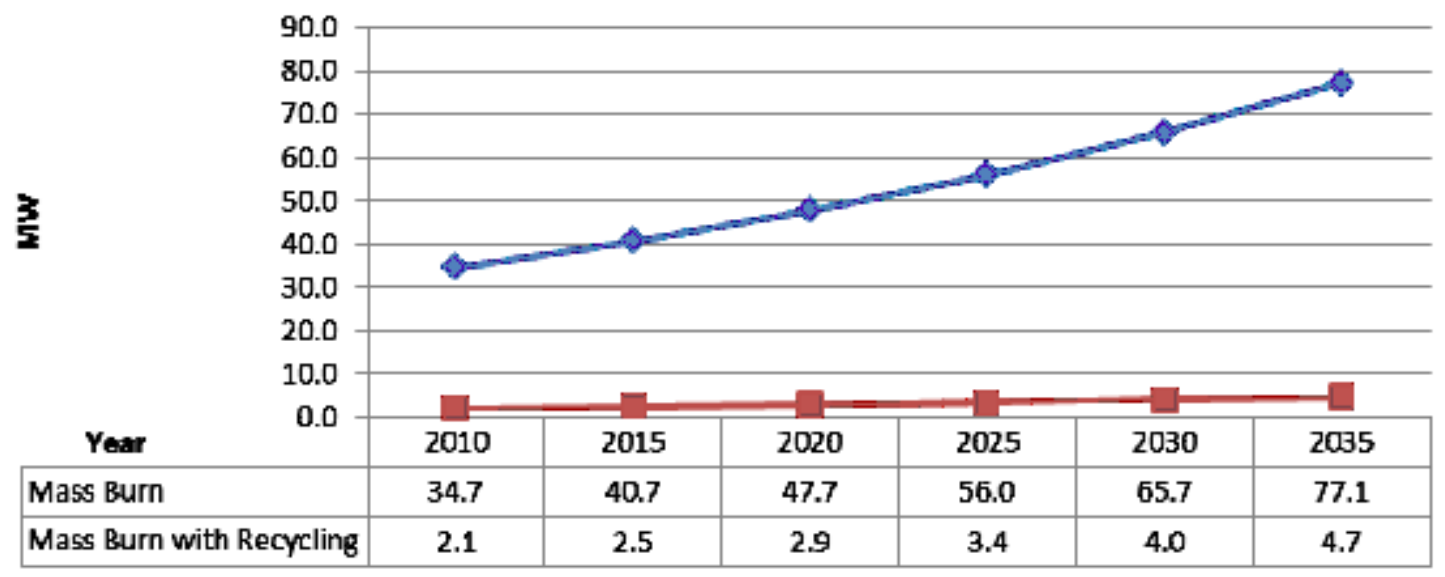

Fig 6: Electricity Production potential for the two Scenarios.

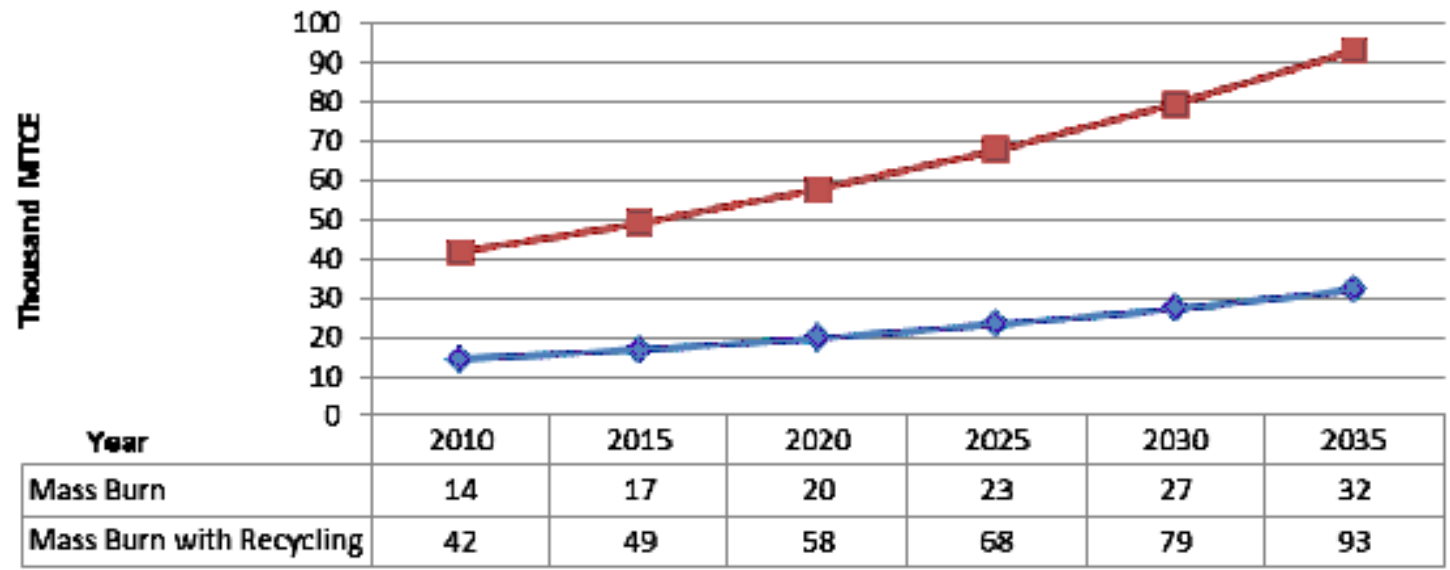

Fig 7:Greenhouse gases emission reduction potential for the two scenarios.

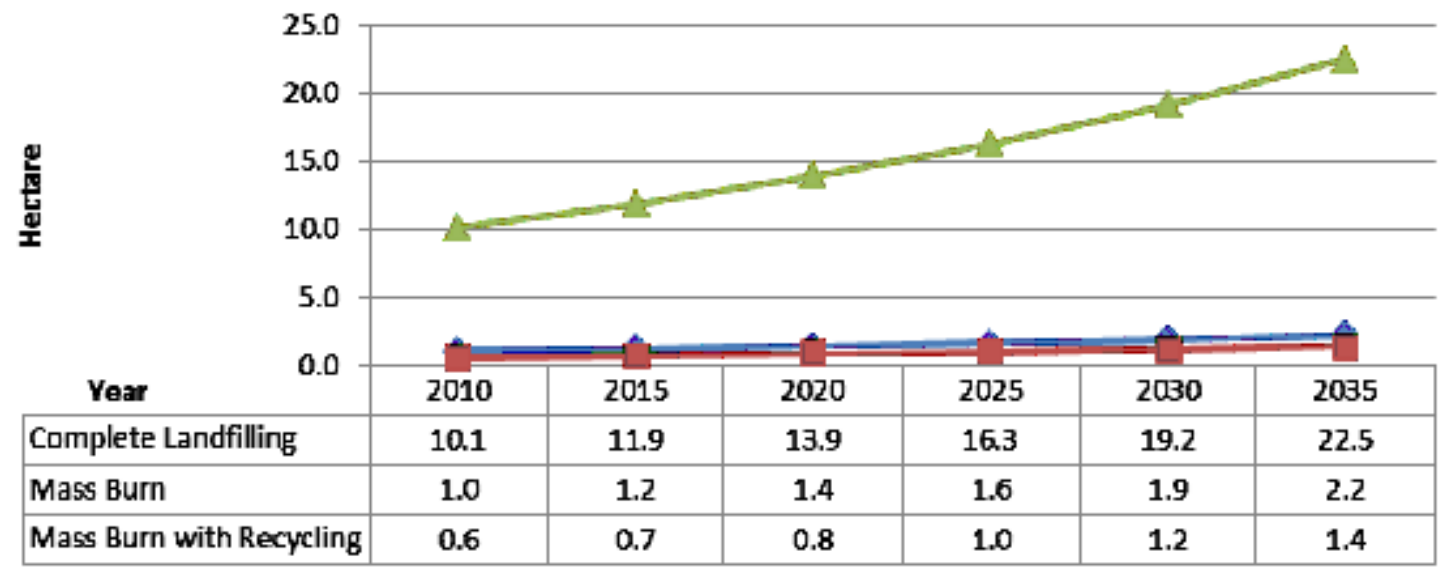

Fig 8: Landfill area requirements complete landfilling and for the two scenarios. 
greenhouse gases emission reductions in Mass Burn scenario is primarily due to the thermal conversion of the landfill methane gas to carbon dioxide through incantation. Methane is 21 times more detrimental than carbon dioxide from the global warming perspective ${ }^{19}$

The potential land saving in comparison to landfilling for Mass Burn with Recycling and Mass Burn scenarios was calculated up to the year 2035 and presented in Fig 8. The figure shows a need for about 22.5 hectare (ha) per year of landfill area for complete landfilling of SW in 2035. This will add a tremendous pressure on Gaza's limited land resources. The implementation of Mass Burn scenario will reduce the landfill area requirement to about 2.2 ha while the Mass Burn with Recycling scenario will reduce yjr landfill area requirement to about 1.4 ha in 2035. In a region like the Gaza Strip, where land resources are very limited, reduction in the area of land needed for landfilling is extremely important.

\section{Conclusion and Recommendations}

The Gaza Strip faces both a serious electricity shortage and SW management problems as a result of thirty years of military occupation and 20 years of political instability coupled a high population growth rate and an unhealthy economic condition. Currently, $28 \%$ of Gaza's electricity demand is supplied by the GPP plant, with the gap between electricity supply and demand being

Table1: Energy content of different types of wastes ${ }^{12,13}$.

\begin{tabular}{lc}
\hline Type of waste & $\begin{array}{c}\text { Energy Content } \\
\text { (Btu/lb) }\end{array}$ \\
\hline Mixed Paper & 6800 \\
Mixed Food Waste & 2400 \\
Mixed Green Yard Waste & 2700 \\
Mixed Plastic & 14000 \\
Rubber & 11200 \\
Leather & 8000 \\
Textiles & 8100 \\
Demolition Softwood & 7300 \\
Waste Hardwood & 6500 \\
Coal & 12300 \\
Fuel, Oil & 18300 \\
Natural Gas & 23700 \\
\hline
\end{tabular}

partially bridged by imported electricity from the neighboring countries. The MSW system is in poor condition resulting from 50 years of neglect and poor management. The option to develop a WTE facility to manage the solid waste problem and to alleviate the electricity shortage has not been previously investigated for the Gaza Strip. This research aims to assess the potential environmental values of waste to energy (WTE) facility in the Gaza Strip considering two scenarios: Mass Burn and Mass Burn with Recycling up to the year 2035. The potential electrical power contributions to the Gaza Strip were assessed by conducting a quantitative forecast analysis of potential WTE electricity production up to the year 2035 for two scenarios: Mass Burn and Mass Burn with Recycling. The Mass Burn with Recycling scenario analysis shows a potential power production of about 4.7 Megawatt (MW) of electricity from MSW in 2035. The Mass Burn scenario results show potential production of $77.1 \mathrm{MW}$, which results in about $10.3 \%$ of the electricity peak demand projected in 2035. There is a substantial difference between the potential electricity productions of the two scenarios as the Mass burn scenario can produce 16 times more power than the Mass Burn with recycling scenario. The results also suggest that there is a significant potential environmental benefit to the Gaza Strip from a WTE facility. An analysis of the potential reduction in greenhouse gases emission shows a potential emission reduction of 32 thousand MTCE per year and 92 thousand MTCE per year for the Mass Burn scenario and Mass Burn with Recycling scenario; respectively, in comparison to the landfilling option to 2035. Furthermore, the landfill area saving for

Table 2: Net greenhouse emission reduction in MTCE per ton of material ${ }^{20}$

\begin{tabular}{lcc}
\hline Materials & $\begin{array}{c}\text { Recycling } \\
\text { versus } \\
\text { Landfilling }\end{array}$ & $\begin{array}{c}\text { Combustion } \\
\text { versus } \\
\text { Landfilling }\end{array}$ \\
\hline Paper & 1.01 & 0.34 \\
Plastic & 0.41 & -0.26 \\
Glass & 0.50 & 0.43 \\
Wood & 0.54 & 0.08 \\
Textiles & 1.97 & 0.10 \\
Organic & 0.12 & 0.12 \\
Others (Mixed MSW) & 0.60 & 0.18 \\
\hline
\end{tabular}


Table 3: Gaza Strip's MSW Energy Contents.

\begin{tabular}{|c|c|c|c|c|}
\hline Material & $\begin{array}{c}\text { Waste } \\
\text { Composition } \\
\%\end{array}$ & $\begin{array}{l}\text { Energy } \\
\text { Content } \\
\text { (Btu/lb) }\end{array}$ & $\begin{array}{c}\mathbf{k W h} / \mathbf{K g} \\
\text { in Material }\end{array}$ & $\begin{array}{c}\text { kWh/Kg } \\
\text { in Waste } \\
\text { HHV }\end{array}$ \\
\hline Paper & 8.4 & 6800 & 4.39 & 0.35 \\
\hline Plastic & 16.1 & 14000 & 9.05 & 1.43 \\
\hline Glass & 2.3 & 0 & 0.00 & 0.00 \\
\hline Wood & 0.8 & 7300 & 4.73 & 0.03 \\
\hline Textiles & 3.8 & 8100 & 5.20 & 0.17 \\
\hline Organic & 60.8 & 2400 & 1.55 & 0.28 \\
\hline Others & 5.0 & 5200 & 3.36 & 0.15 \\
\hline \multirow{2}{*}{\multicolumn{5}{|c|}{$\begin{array}{l}\text { Total Energy for Mass Burn with Recycling scenario }(\mathrm{kWh} / \mathrm{kg}) \\
\text { Total Energy contents of Mass Burn scenario }(\mathrm{kWh} / \mathrm{kg}) \\
\text { Table 4: Net greenhouse gases reduction in MTCE per ton of } \\
\text { SW material for the two scenarios. }\end{array}$}} \\
\hline & & & & \\
\hline \multicolumn{2}{|l|}{ Materials } & $\begin{array}{c}\text { Waste } \\
\text { Composition } \\
\%\end{array}$ & $\begin{array}{c}\text { Mass Burn } \\
\text { with Recycling } \\
\text { (MTCE/ton of SW) }\end{array}$ & $\begin{array}{l}\text { Mass Burn } \\
\text { (MTCE/ton of } \\
\text { MSW) }\end{array}$ \\
\hline \multicolumn{2}{|l|}{ Paper } & 8.4 & 0.08 & 0.03 \\
\hline \multicolumn{2}{|l|}{ Plastic } & 16.1 & 0.07 & -0.04 \\
\hline \multicolumn{2}{|l|}{ Glass } & 2.3 & 0.01 & 0.01 \\
\hline \multicolumn{2}{|l|}{ Wood } & 0.8 & 0.00 & 0.00 \\
\hline \multicolumn{2}{|l|}{ Textiles } & 3.8 & 0.07 & 0.00 \\
\hline \multicolumn{2}{|l|}{ Organic } & 60.8 & 0.07 & 0.07 \\
\hline \multicolumn{2}{|c|}{ Others } & 7.8 & 0.03 & 0.01 \\
\hline \multicolumn{2}{|c|}{ TOTAL (MTCE/ton of SW } & & 0.34 & 0.08 \\
\hline
\end{tabular}

Mass Burn and Mass Burn with Recycling scenario is about $90 \%$ and $94 \%$ respectively in comparison to landfilling. Further investigations are recommended to compare the two scenarios with respect to financial, social, and technical criteria. Further site specific environmental studies should also be conducted including the potential impacts on groundwater and soil from the current practice of landfilling. The socio-economic studies should consider WTE production costs, recycling values, job creation, and human capacity-building opportunities. The technical studies should be focused on determining optimum WTE technologies to be implemented in the Gaza Strip.

\section{REFERENCES}

1. Ouda O. K., Optimization of Agricultural Water Use: A Decision Support System for the Gaza Strip, Institute of Hydraulic Engineering, Stuttgart University, pp.150 (2003).

2. PCBS Palestinian Central Bureau of Statistics, Population in the Palestinian territory 1997-202. Ramallah, Palestine
(1999).

3. PCBS Palestinian Central Bureau of Statistics, On the Eve of the International Population Day 11/07/2012, (2011). Available online at http://www.pcbs.gov.ps/ Portals/_pcbs/PressRelease/ int_Pop_2012e.pdf. Accessed on May 15th, 
2013.

4. El Baba, M. Y.; De Smedt, F., Solid Waste Management and Practices in Gaza Strip (Palestine). 6th International Perspective on Water Resources \& Environment. Izmir, Turkey (2013).

5. UN, the Humanitarian Impact of Gaza's Electricity and Fuel Crisis. United Nations, Office for the Coordination of Humanitarian Affairs (2012a).

6. UN, Gaza in 2020 A livable Place?, A report by the United nations Country Team in the occupied Palestinian territory (2012b).

7. Gisha, Electricity Shortage in Gaza: Who turned Out the Lights? Position Paper, GishaLegal Centre for Freedom of Movement (2010).

8. Al Hmaidi, M., The development of a strategic waste management plan for Palestine, Review of the current situation: handling, transportation and disposal of waste, Negotiations Support Unit. Negotiations Affairs Department. Palestine (2002).

9. PNA, Energy Sector Strategy, Palestinian National Plan 2011-2013. Palestinian National Authority, Ramallah, Palestine (2011).

10. UNDP-PAPP, Final report for Feasibility Study and Detailed Design for Waste Management in the Gaza Strip, UNDP-PAPP, DHV ENFRA TECC (2012)

11. Young, G. C., Municipal Solid Waste to Energy Conversion Processes: Economic, Technical, and Renewable Comparisons, first ed., John Wiley, Hoboken, New Jersey (2010).

12. Ouda, O. K. M.; Cekirge, H. M.; Raza, S. A., An assessment of the potential contribution from waste-to-energy facilities to electricity demand in Saudi Arabia. Energy Conversion and Management, 75 402-406. (2013).

13. Gilbert, M.M.; Wendell, P.E., Introduction to Environmental Engineering and Science, Chapter 9: Solid Waste Management and Resource Recovery, Third Edition, Pearson
Education Inc. ISBN-13: 978-0-13-2339346 (2008).

14. UNEP, United Nations Environmental Program, International Source Book on Environmentally Sound Technologies for Municipal Solid Waste Management. Osaka/ Shiga (1996).

15. ASME American Society of Mechanical Engineers, Waste-to-Energy: A renewable Energy Source from Municipal Solid Wastes, White paper submitted to the Congress (2008).

16. Cheng, H.; Hu,Y., Review Municipal solid waste (MSW) as a renewable source of energy: Current and future practices in China, Bioresource Technology, 101, 38163824. (2010).

17. Rogoff, M. J.; Screve, F., Waste to Energy, second ed., Elsevier, New York (2011).

18. Kathirvale ,S.; Yunus, M. N. M.; Sopian , K.; Samsuddin, A. H., Energy potential from municipal solid waste in Malaysia. Renewable Energy, 29, 559-567 (2003).

19. Psomopoulos,C. S.; Bourka, A.; Themelis, N. J., Waste-to-energy: A review of the status and benefits in USA, Waste Management, 29, 1718-1724 (2009).

20. US EPA, Solid Waste Management and Greenhouse Gases, A life-Cycle Assessment of Emission and Sinks. $3^{\text {rd }}$ ed., Washington, US, (2006).

21. Al Ansari M.S, Improving Solid Waste Management in Gulf Co-operation Council States: Developing Integrated Plans to Achieve Reduction in Greenhouse Gases, Modern Applied Science, 6(2), (2012), Doi:10.5539/mas.v6n6p60.

22. Abu Samah M. A.; Abd Manaf L.; Aris A.Z.; Sulaiman W.N.A., Solid Waste Management: Analytical Hierarchy Process (AHP) Ppplication of Selecting Treatment Technology in Sepang Municipal Council, Malaysia, Current World Environment, 6(1), 1-16 (2011) 